\title{
Research of Mining Industry of TAR amid Construction of Silk Road Economic Belt
}

\author{
Xi Zhang ${ }^{\mathrm{a}}$, Genhou Wang ${ }^{\mathrm{b}}$ and Nan Xiao ${ }^{\mathrm{c}}$
}

School of Earth Sciences and Resources, China University of Geosciences,Beijing 100083, China;

azx405415294@sina.com, bwgh@cugb.edu.cn, camyshaw@163.com

Keywords: Silk Road Economic Belt, Tibetan mining industry, research of development

\begin{abstract}
Situated at the junction between Gondwana continent and Eurasian continent (plate), Tibet Autonomous Region (TAR) is the world's key ore-forming region. Based on the large quantity of data that had been obtained on-site, the study summarizes the distribution, prospection and mining enterprises for competent mine resources in TAR, and identifies the shares of Tibetan mining sector in heavy industry, industry and GDP, as well as the contribution of the mining economy, so as to make a conclusion that mining plays a role in accelerating the economic development of Tibet from 2009 and 2013. On top of that, the study analyzes the impacts of the Tibetan mining industry on the livelihood of people. The study shows that the diffusion and boosting roles of the mining industry have not yet been given into better play. The construction of Silk Road Economic Belt is expected to bring huge opportunities to the development of Tibetan mining industry. In line with the characteristics, the paper puts forward to pertinent policies and suggestions for TAR to be plugged into the construction of Silk Road Economic Belt.
\end{abstract}

Situated in the southwest frontier of China, Tibet Autonomous Region (TAR) covers a total area of 1,228,000 square kilometers. With an above mean sea level of over 4,000 meters, Tibet is often called "roof of the world" and "the third pole". Since Tang Dynasty, the region has established business and trade relations with places along Ancient Silk Road through Ancient Tangbo Road, Tea Horse Road and post road. It is also the land route linking China with countries in South Asia and Southeast Asia. Following President Xi Jinping's call to jointly build “Silk Road Economic Belt” in September 2013, National Development and Reform Commission, Ministry of Foreign Affairs and Ministry of Commerce jointly issued on March 28, 2015 the Vision and Actions on Jointly Building Silk Road Economic Belt and 21st-Century Maritime Silk Road, which has involved 18 major provinces in the final version. Of them, 3 southwestern provinces include Guangxi, Yunnan and TAR. The construction of Silk Road Economic Belt will bring about unprecedented historical opportunities for TAR to realize a leap in terms of economic and social development. TAR' s economy will be further promoted thanks to the construction of Bangladesh-China-India-Myanmar and China-Pakistan economic corridors. Active participation in the construction of Silk Road Economic Belt is of great significance to the social and economic development of TAR.

\section{Overview of dominant mineral resources, prospecting, and development in TAR}

Situated at the junction between Gondwana continent and Eurasian continent (plate), TAR is the world's key ore-forming region. Boasting abundant mineral resources, TAR is one of China's key mineral reserve bases, too. Its main mineral resources include chromium, copper, molybdenum, lead, zinc, iron, gold, silver, salt lake and high temperature geothermal. Key ore-forming belts like Gangdise, Bangong Lake-Nujiang River, 3 major rivers of Southwest China boast great potentials for mineral resources. Key oil and gas basins and salt lakes in Qingtang and Kekexili are expected to embrace a good outlook.

The degree of development and utilization of mineral resources in TAR scales down from east to west. The mining right is mainly possessed by East TAR, while the prospecting right by central and northwestern part of TAR. The geological prospecting work of TAR is at the lowest level of China, 4 five-year plans behind the inland regions. Therefore, during the 12th Five-year Plan period, TAR 
speeded up the prospecting and development of dominant mineral resources, with a priority of mineral prospecting given to regions along Qinghai-Tibet Railway, east section of Gangdise in Central Tibet, Nyainqentanglha ore-forming belt and three-river region in East Tibet, which are helpful in ore-forming. The development has been accelerated for dominant mines such as copper, chromium, and salt lake mines, which are badly needed by the nation and are often imported from abroad. As to copper, many large copper mines have been completed and put into production, including China National Gold Group Corporation (JJiama copper-polymetallic mine), Tibet Mining Development Co., Ltd.(Nimu Tinggong copper mine), Western Mining(Jade dragon copper mine), Yunnan Copper Industry Group(Nimu copper mine), Sichuan Hongda Co., Ltd.(Bangpu copper and molybdenum mine), Jinchuan Group Co., Ltd.(Xiongcun gold \& copper mine) and Qulong project. TAR is expected to see its annual copper production capacity to exceed 300,000 tons in 2015, with the share in the domestic market rising from 1\% in 2010 to 22\%. As to salt lake development, some new projects or expansion ones have been put into production, including Tibet Mining(Zabuye), Tibet Urban Development and Investment Co.,Ltd.(Jiezechaka, Longmucuo) and Chagcam Caka, etc. The region's annual lithium carbonate production capacity will be over 50,000 tons in 2015, with the share in domestic market rising from 7\% in 2010 to 38\%. TAR is being built into China's most important base for comprehensive utilization of copper and salt lake, relieving the bottleneck for mineral resources development and ensuring industrialization for the region.

\section{Development of TAR's Mining Industry and Contributions to National Economy}

TAR is on the fast track of the development mining economy. The total mining production value increased to 5.77137 billion yuan in 2013 from 627 million yuan in 2005, with the share in total industrial value rising from $29.0 \%$ to $45.86 \%$. The proportion of TAR' s mining production value in GDP was 5.59\%, 6.01\%, 6.69\%, 6.80\%, and7.15\% respectively from 2009 to 2013, namely, from the end of 11th Five-year Plan Period to 12th Five-year Plan Period. The proportion remains very low compared with construction and tourism sectors although it is on a rise.

Development and utilization of mines plays a role of diffusion and boosting. To measure its contributions to national economy, we need to consider not only the proportions of mining production value in industrial value and regional production value, but also its effects to downstream sectors and people's livelihood. Through filed research and collection of data and documents in a large quantity, we produce the proportions of Tibet's mining sector in heavy industry, industry and GDP, as well as contribution of mining economy between 2009 and 2013. The formulas are as follows:

$\mathrm{R}=(\mathrm{a} * \mathrm{Z}) \mathrm{P} * 100 \%$.

R-Growth of mining economy contribution; a-Proportion of mining production value in total production value; Z-Growth of mining production value; P-Growth of total production value.

As shown in Table 2-1, proportion of mining production value in heavy industry's production value ranges from $63.86 \%$ to $74.25 \%$, which is very high. That in industrial production value reaches 45.86\%, nearly a half. Between 2009 and 2013, however, the growth rate of both mining production value and GDP fluctuated sharply, resulting in a big fluctuation of growth of mining economy contribution: $11.36 \%$ in 2011, but down to $9.94 \%$ in 2013 . This indicates that growths of mining production value and GDP change in a same direction, exerting positive effects. Between 2009 and 2013, the growth of mining economy contribution is higher than the proportion in GDP, suggesting an acceleration of mining to boost the economic development of Tibet.

\section{Opportunities Brought by Construction of Silk Road Economic Belt to Mining Industry}

“One Belt, One Road” strategy has seen a period of favorable policies since it was put forward in 2013. Government ministries are working together to push the implementation of the strategy, including local plans in coordination with the plans of the central government. 
China needs to open up a west energy passage and identify various channels of import in the context of geopolitics. Opening up westward is not just a second industrial transfer, but also facilitates the transportation efficiency with European countries, as well as enhances cooperation with Central Asia in terms of resources, services and trade. China and Central Asian countries always enjoy pleasant cooperation in oil and gas for a long time. Modernized cross-border railways, roads, natural gas pipelines will be built into a comprehensive network. China-Pakistan Economic Corridor has laid a foundation for Maritime Silk Road. Given no maritime exit in Central Asia, such countries as Turkmenistan and Kyrghyzstan are expected to embrace a leap in export if the Silk Road Economic Belt is opened as "Euroaisa Continent Bridge". Meanwhile, enhanced cooperation with China will be a great momentum for their development. This will also bring great historical opportunities to the development of Tibetan mining industry.

Table 2-1 2009-2013 Tibet’s Growth of Mining Economy Contribution

\begin{tabular}{|c|c|c|c|c|c|c|c|c|}
\hline Year & $\begin{array}{l}\text { Mining } \\
\text { Productio } \\
\text { n Value } \\
(100 \\
\text { million } \\
\text { yuan) }\end{array}$ & $\begin{array}{l}\text { Growth of } \\
\text { Mining } \\
\text { Productio } \\
\text { n Value }\end{array}$ & $\begin{array}{l}\text { GDP } \\
\text { Growth }\end{array}$ & $\begin{array}{c}\text { Propor } \\
\text { tion in } \\
\text { GDP }\end{array}$ & $\begin{array}{l}\text { Growth } \\
\text { of } \\
\text { Mining } \\
\text { Economy } \\
\text { Contribut } \\
\text { ion }\end{array}$ & $\begin{array}{l}\text { Proportion } \\
\text { in } \\
\text { Industrial } \\
\text { Production } \\
\text { Value }\end{array}$ & $\begin{array}{c}\text { Producti } \\
\text { on Value } \\
\text { of Heavy } \\
\text { Industry( } \\
100 \\
\text { million) }\end{array}$ & $\begin{array}{l}\text { Proportion in } \\
\text { Heavy Industry }\end{array}$ \\
\hline 2009 & 24.6671 & - & $11.78 \%$ & $5.59 \%$ & - & $37.49 \%$ & 38.6241 & $63.86 \%$ \\
\hline 2010 & 30.4940 & $23.62 \%$ & $14.98 \%$ & $6.01 \%$ & $9.48 \%$ & $40.33 \%$ & 47.9697 & $63.57 \%$ \\
\hline 2011 & 40.5310 & $32.91 \%$ & $19.38 \%$ & $6.69 \%$ & $11.36 \%$ & $42.63 \%$ & 58.0872 & $69.78 \%$ \\
\hline 2012 & 47.6408 & $17.54 \%$ & $15.71 \%$ & $6.80 \%$ & $7.59 \%$ & $44.98 \%$ & 65.2380 & 73.03\% \\
\hline 2013 & 57.7137 & $21.14 \%$ & $15.21 \%$ & $7.15 \%$ & $9.94 \%$ & $45.86 \%$ & 77.7260 & $74.25 \%$ \\
\hline
\end{tabular}

\section{Research of Mining Industry of TAR amid Construction of Silk Road Economic Belt}

(1)Promote transportation capacity of Qinghai-Tibet Railway, backed by Qinghai-Tibet Industrial Park, and get plugged into Silk Road Economic Belt.

(2)Strengthen R\&D on new technology and new process, promote research on integrated application of mining resources.

(3)Strengthen R\&D on new technology and new process, promote research on integrated application of mining resources.

(4) Expand external and internal open-up, robustly develop open economy.

\section{References}

[1] Li Mingli, Qiu Yanqing, etc. Development Status and the Countermeasures of Mining Cycle Economy in Tibet [J] Tibet’s Science \& Technology, 2010, 06:26-28.

[2]Jiang Liqun. Tibet Mining's Influence and Analysis on Urbanization [J]. Natural Resource Economics of China, 2005, 05:22-24.

[3] Li Hongyi, Wang Xiaodan. Three Aspects of Balanced Development in Future [J].China Metal Bulletin, 2010, 18:34-35.

[4] Wu Qiang. Analysis of Economic Effect on Tibet Mining Development [J].Mining Research and Development, 2006, 26(2): 4-6.

[5] Gu Guoai. Countermeasures for "One Belt and One Road” on Tibet Development [J]. China Business and Market, 2015, 5:113-118.

[6] Miao Yang, Jiang Yi. Leaping Development in Tibet pushed by Integrated “One belt and One Road” Strategy [J]. Contemporary World, 2015, 1:71-72. 